\title{
Obecność przypisu w edycji cyfrowej - rekonesans
}

\section{KonRad NiciŃski}

ORCID: 0000-0003-0465-8806

(Instytut Badań Literackich PAN, Warszawa)

Czy w czasach edycji cyfrowej potrzebny jest jeszcze przypis? Pytanie na pierwszy rzut oka brzmi obrazoburczo, ale wydaje się uzasadnione. Istnienie czegoś takiego jak przypis wynika z odpowiednich potrzeb i warunków druku; środowisko cyfrowe daje sposobność do radykalnej zmiany. Właśnie pod względem opatrywania treści komentarzem, włączenia do niej poziomu metatekstu, przenikania się w jej obrębie różnych tekstów lub rozmaitych ich wariantów, możliwości środowiska cyfrowego są znacznie większe niż te, do których przyzwyczaił nas druk. Co więcej, możliwości te są nie tyle szersze, ile inne. Łączą bowiem model myślenia o komentarzu, do którego przywykliśmy, obcując z wydaniami papierowymi, z możliwościami publikacji, które w swojej genezie nie zasadzają się na przekształceniu druku - z cechującą go dwuwymiarowością - czyli na utożsamieniu ekranu z kartką papieru, a przeciwnie, polegają na równoczesnym wykorzystaniu wielu płaszczyzn czy odwzorowań kilku przestrzeni. Potrzeby i warunki środowiska cyfrowego są inne, a zatem wymuszają inne rozwiązania - i być może także odmienny sposób myślenia o tekście i komentarzu do niego. Pytanie, czy do tego dojdzie, pozostaje otwarte. Otwarte również dlatego, że określenie „czasy edycji cyfrowej” wydaje się jeszcze niestosowne do warunków, w których obecnie pracujemy. Nie tylko w Polsce, gdzie projekty naukowej edycji cyfrowej tekstu literackiego lub źródłowego dopiero wchodzą w fazę realizacji albo nadal na nią oczekują ${ }^{\mathrm{I}}$. Także w Europie Zachodniej czy w Stanach Zjednoczonych, gdzie takie wydania stały się już widoczną częścią sztuki edytorstwa

1 Zob. M. Śliwińska, Dzieła zebrane Zygmunta Krasińskiego - elektroniczna edycja naukowa, „Sztuka Edycji” 2014, nr 1/2, s. 69-75; zob. także wielce dyskusyjny zarówno z perspektywy edytorstwa tradycyjnego, jak i cyfrowego artykuł Pawła Bema Dlaczego polskie edytorstwo naukowe nie istnieje („Teksty Drugie” 2016, nr 1, s. 151-168). 
naukowego, wciąż mówimy raczej o procesie poszukiwania i tworzenia rozwiązań. Wydaje się ponadto, że nie sposób mówić gdziekolwiek o wyparciu druku przez rozwiązania cyfrowe czy o sytuacji, w której to edycje cyfrowe wyznaczają kanon myślenia o pracy edytorskiej. Czasy edycji cyfrowej przypuszczalnie zaczynają się właśnie na naszych oczach czy nawet przy naszym udziale, ale mogą być też - tylko i aż - jednym $z$ wariantów nadchodzącej przyszłości, bardzo prawdopodobnym, acz niecałkowicie pewnym. Nie zapominajmy bowiem, że choć łatwość dostępności czy szybkość przekazywania informacji w środowisku cyfrowym znacznie przewyższa możliwości druku, to już większa trwałość rozwiązań cyfrowych wcale nie jest rzeczą oczywistą. Jeśli uznać zatem „czasy edycji cyfrowej” za nadchodzący, potencjalny stan zmiany sposobu myślenia o edytorstwie naukowym, to czy na podstawie obserwowanych przez nas poszukiwań środków właściwych dla przygotowania edycji cyfrowej możemy stwierdzić, że przypis znajdzie w niej w ogóle swoje miejsce? Czy tak prowokacyjnie brzmiące pytanie jest jednak uzasadnione? Wydaje się, że tak.

Rozwój narzędzi służących cyfrowej edycji naukowej tekstu idzie w kierunku przejmowania przez tak zwane znaczniki funkcji spełnianych dotąd przez przypisy. Teoretycznie można sobie zatem wyobrazić sytuację, w której znaczniki, stanowiące w tego rodzaju edycji podstawowe narzędzie i w o wiele większym stopniu niż przypisy wykorzystujące właściwości środowiska cyfrowego, powoli będą stawały się dla kolejnych pokoleń edytorów tak naturalnym narzędziem jak dotąd przypis, i to one staną się podstawowym sposobem myślenia o komentarzu w naukowym wydaniu tekstu. Tego rodzaju prognozowanie przyszłości przekracza być może kompetencje nas jako osób starających się zajmować nauką. Stanowi jednak, jak sądzę, dobry punkt wyjścia, by opisać to, do czego jesteśmy zdolni już teraz: jakie szanse i ewentualnie jakie kierunki zmiany myślenia o komentarzu przynosi znacznik.

Zacznijmy od spraw najprostszych: czym jest znacznik i dlaczego to edytor, a nie programista, powinien się nim interesować? Najogólniej można rzec, że znaczniki stanowią podstawowe narzędzie opracowania tekstu w cyfrowych dokumentach hipertekstowych. Powszechnie wykorzystywane w Internecie formaty HTML i XML są niczym innym, jak językiem złożonym ze znaczników. Dlatego też wydaje się nader oczywiste, że zajmują one nie tylko programistów, ale także edytorów czy - szerzej - badaczy literatury zainteresowanych wykorzystaniem podczas pracy nad tekstem narzędzi cyfrowych. „Znacznik” jest terminem bardzo ogólnym, odnoszącym się właściwie do każdego rodzaju określenia pozycji słowa czy znaku w pliku typu HTML czy XML. Tym, co najogólniej rzecz ujmując, może być dla edytora interesujące, są formy oznaczania tekstu, pozwalające grupować obecne w nim słowa w wyszukiwalne i przeszukiwalne kategorie, poczynając od najprostszych, jak imię i nazwisko czy nazwa miejsca, po bardziej skomplikowa- 
198

ne, wiążące się z kontekstem czy sposobem wykorzystania w tekście. Widomym skutkiem tego rodzaju poszukiwań jest rozwijany z powodzeniem od I994 roku (przy czym początki prac datuje się na rok 1987) standard oznaczenia tekstu TEI (Text Encoding Initiative) ${ }^{2}$, który jest obecnie standardowym narzędziem oznaczania tekstu w naukowej edycji cyfrowej. TEI stanowi rozszerzenie języka XML stworzone i rozbudowywane z myślą o naukowej edycji tekstu. W związku z tym składają się nań znaczniki pozwalające na wszechstronny i precyzyjny opis tekstu źródłowego, jego cech kompozycyjnych, językowych, stanu fizycznego dokumentu (między innymi dokładny opis skreśleń, nadpisań, ubytków), a także zmian edytorskich. Podzielono je na dwie grupy: podstawowe - elements i dopełniające (doprecyzowujące) - attributes. W ten sposób TEI daje możliwość zarówno bardzo wszechstronnego opisu tekstu, jak i precyzyjnej klasyfikacji użytych kategorii; warto też dodać, że system ten nie jest zamknięty - za zgodą władz konsorcjum może być rozszerzany, najczęściej na podstawie doświadczeń zespołów badawczych i edytorskich korzystających z TEI i natrafiających podczas pracy na potrzebę uzupełnienia istniejących oznaczeń. Oczywiście poza znacznikami opisującymi tekst źródłowy i zmiany, jakim on podlega, TEI pozwala również na dość precyzyjną kategoryzację „bytów” w nim występujących, przede wszystkim osób (zarówno person rzeczywistych, jak i postaci literackich), ale także miejsc, utworów, czasopism czy organizacji. Zwłaszcza tu otwiera się przestrzeń możliwych przemian przypisu. Znacznik bowiem per se nie stanowi (czy raczej - nie musi stanowić) całości tego, co widzi odbiorca - o reprezentacji wizualnej znacznika decydują dla każdego projektu jego autorzy. W praktyce oznacza to, że stosunkowo łatwo, nie naruszając spójności systemu znaczników, można je uzupełnić opisem. To już pozwala na przekroczenie granicy między indeksacją a aparatem komentarzy w o wiele większym stopniu niż dotychczas w rozbudowanych deskrypcjach dołączanych do indeksów osobowych i rzeczowych (skądinąd w ostatnich dekadach spotykanych coraz rzadziej).

Większość przykładów i refleksji zawartych w tym tekście powstała na kanwie pracy nad edycją cyfrową podczas realizowanego w IBL PAN pod kierownictwem dr hab. Beaty Dorosz grantu NPRH Skamandrycka triada na emigracji. Edycja listów Jana Lechonia, Kazimierza Wierzyńskiego i Mieczystawa Grydzerwskiego (publikacja ksiqżkowa $i$ cyfrowa). W jego ramach wydano już blok korespondencji między Lechoniem a Wierzyńskim³ ${ }^{3}$, składający się z 219 listów, który stał się też podstawą

2 Warto zauważyć, że istotną rolę w zbudowaniu systemu TEI odegrały doświadczenia pierwszego i przez wiele lat jedynego polskiego zespołu zajmującego się edycją cyfrową, działającego obecnie przy Wydziale „Artes Liberales” Uniwersytetu Warszawskiego, który pod kierunkiem dr hab. Anny Skolimowskiej opracowuje spuściznę Jana Dantyszka.

3 Zob. J. Lechoń, K. Wierzyński, Listy, oprac. B. Dorosz, Warszawa 2016. 
realizowanej właśnie edycji cyfrowej ${ }^{4}$. Ponad ııoo listów Kazimierza Wierzyńskiego i Mieczysława Grydzewskiego jest obecnie przygotowywanych do wydania; dodajmy, że prace nad wersją książkową i cyfrową są prowadzone równolegle.

Podczas pracy nad edycją emigracyjnej korespondencji skamandrytów przyjęto założenie, że całość korpusu będzie miała dwa równoczesne wydania, tradycyjne (papierowe) i elektroniczne. Po części zrodziło się ono z przekonania, że edycje tradycyjna i cyfrowa są adresowane do różnych kręgów czytelników i stawiają przed sobą odmienne cele - trudno zastąpić książkę innym medium w lekturze ciągłej, od deski do deski; w zakresie wyszukiwania i grupowania informacji przewaga narzędzi cyfrowych nad tradycyjnymi jest z kolei wyraźna, choćby tylko ze względu na rozmaitość dostępnych kryteriów. Po części jednak szło tu o empiryczne sprawdzenie, co ulega zmianie podczas adaptacji naukowej edycji listów - przygotowanej zgodnie ze sztuką z myślą o tradycyjnym wydaniu - do narzędzi cyfrowych. Stąd także pierwsza część korpusu, listy Jana Lechonia i Kazimierza Wierzyńskiego, została najpierw wydana w wersji książkowej, a dopiero później „przełożona” na język edycji cyfrowej. Ta kolejność działań okazała się właściwą ścieżką - oczywiście spodziewaliśmy się, że nie wszystko, do czego jesteśmy przyzwyczajeni podczas przygotowywania edycji tradycyjnej, można zastosować w warunkach cyfrowych. Jednakowoż praca nad przeniesieniem przypisów do edycji cyfrowej zmusiła nas - i to w stopniu większym niż się spodziewaliśmy - do namysłu nad tym, jak silnie warsztat edytorski jest uwarunkowany realiami wydania książkowego.

Jeszcze przed podjęciem „translacji” tradycyjnych przypisów na język cyfrowy zdecydowaliśmy o wyodrębnieniu pięciu kategorii, które nie tylko będą opisywane znacznikami TEI, ale otrzymają również wyraźną reprezentację wizualną. Są to: osoby, miejsca, utwory (rozumiane zarówno jako pojedynczy utwór, jak i jako tom czy też cykl), czasopisma i organizacje. Zatem każdemu oznaczeniu w tych kategoriach będzie towarzyszyła nota, mogąca zawierać na przykład opis, charakterystykę czy biogram. W ten sposób każde $\mathrm{z}$ tak wyodrębnionych oznaczeń łączy funkcje, które w pracy edytorskiej zwyczajowo przypisywalibyśmy z jednej strony indeksowaniu (osób, miejsc, dzieł itd.), z drugiej zaś - opatrywaniu tekstu komentarzem. Prawdopodobnie najprostszym rozwiązaniem tego problemu byłoby potraktowanie towarzyszących oznaczeniom opisów nie jak przypisów biograficznych, a jako możliwie skrótowych not, analogicznych do tych, jakimi można uzupełnić (choć to obecnie niezwykle rzadka praktyka) indeks osobowy. W takiej sytuacji przypisy zachowałyby swój charakter - zostałyby włączone do edycji cyfrowej w takiej samej formie, jak w wydaniu tradycyjnym. Sens poznawczy powyższego zabiegu byłby jednak nikły. O bohaterze noty dowiadywalibyśmy się niewiele (daty życia, podsta- 
wowa informacja o zawodzie czy też piastowanych stanowiskach), a dotyczących tej osoby przypisów nie można byłoby zebrać razem. W gruncie rzeczy zatem edycja cyfrowa oznaczałaby wtedy nieco bardziej efektywną formę indeksacji.

Osobną kwestią wymagającą rozwiązania pozostaje kształt przypisu biograficznego w polskich edycjach naukowych. Oczywiście mamy do czynienia i z edytorami, którzy formułują noty biograficzne wyjątkowo oszczędnie (jak znakomity skądinąd Andrzej S. Kowalczyk)5 ; najczęściej jednak w polskiej szkole edycji nota biograficzna w przypisie stanowi skrót najważniejszych zdarzeń w biografii, prac i dzieł jej bohatera, jest zatem znacznie obszerniejsza niż najogólniejsza charakterystyka i zdecydowanie przynależy do przypisu, nie do noty towarzyszącej indeksowi osób. Wprawdzie podstawę prac nad edycją cyfrową korespondencji „skamandryckiego trójkąta" stanowiły przypisy opracowane pod kierunkiem prof. Beaty Dorosz ${ }^{6}$. Cechą charakterystyczną warsztatu tej badaczki jest wyjątkowo bogate i szczegółowe przywoływanie w przypisach informacji biograficznych, ale wydaje się, że nawet gdyby udało się usytuować możliwie najbliżej postulowanego przez prof. Romana Lotha punktu równowagi ${ }^{7}$, to problem przypisu osobowego znacznie wykraczającego poza zakres noty indeksowej pozostanie bez zmian.

W jaki zatem sposób odejść od indeksacji, aby jak najpełniej przedstawić przypisy biograficzne w środowisku cyfrowym? Pierwszy krok to oczywiście wykorzystanie w opisach znaczników TEI jak najpełniejszych przypisów biograficznych. Drugi ruch, logicznie powiązany z możliwościami stosowanego systemu, to uczynienie całości z biogramu towarzyszącego znacznikowi TEI, stale identyfikującego w tekście tę samą osobę, i zbioru informacji w tekście tej osoby dotyczących. Łączy się to z powiązaniem znacznika (opatrzonego notą biograficzną) z wygodnym dla przyszłego użytkownika zebraniem w jednym miejscu wszystkich słów nim opatrzonych, czyli przypisanych tej osobie. Co mniej oczywiste, a z perspektywy cyfrowych przemian przypisów znacznie ważniejsze, możliwe jest też zebranie w ten sposób wszystkich not odnoszących się do danej osoby. Rozwiązaniem problemu może być na przykład zastosowane w cyfrowej edycji korespondencji „skamandryckiego trójkąta" podzielenie opisu znacznika na dwie części: stałą, pojawiającą się przy każdym jego wykorzystaniu (gdzie umieszczamy biogram), i zmienną, kontekstową, ważną tylko w tym miejscu tekstu. Rozwiązanie takie pozwala także na łatwe zebranie wszystkich przypisów (w tym wypadku - not kontekstowych) dotyczących danej osoby. To z kolei jest tyleż niemałą zdobyczą, ile niemałym wy-

5 Zob. m.in. J. Giedroyc, W. Gombrowicz, Listy 1950-1969, oprac. A.S. Kowalczyk, Warszawa 1993.

6 Zob. J. Lechoń, K. Wierzyński, Listy.

7 Rozumianego jako pozostawienie wylącznie niezbędnych informacji przy jednoczesnej kompletności podstawowych wiadomości biograficznych. Zob. R. Loth, Podstawowe pojęcia i problemy tekstologii i edytorstwa naukorwego, Warszawa 2006, s. 158-159. 
zwaniem, oznacza bowiem, że całość przypisów dotyczących danej osoby w o wiele większym stopniu niż dotychczas tworzy narracyjną całość, co musi wiązać się ze zmianami warsztatowymi w pracy edytora - co jednak stanowi osobne zagadnienie, które zostanie omówione w końcowej partii tego artykułu.

Problemu podziału not czy też not kontekstowych nie rozwiąże wyłącznie system znaczników, wymaga to powiązania ze stosownie napisanym protokołem CSS, niemniej jednak stanowi on rozwiązane w systemie TEI dopuszczalne. Ostatecznie każdy system znaczników potrzebuje właściwych protokołów odpowiadających za jego reprezentację wizualną. Podobne do edycji listów skamandrytów, choć mniej rozbudowane rozwiązanie zastosowano w powstającej jednocześnie edycji zasobów Archiwum Ricordi w Mediolanie ${ }^{8}$. Inne - i chyba lepsze, lecz wynikające $\mathrm{z}$ tych samych przesłanek - zaproponował zespół pod kierunkiem profesora Johna Bryanta z nowojorskiego Hofstra University opracowujący cyfrową edycję dzieł Hermana Melville'a ${ }^{9}$. Zastosowano tam pośredni ekran, umożliwiający wybór między rodzajami komentarza (czyli na przykład między ogólnym biogramem a przypisem kontekstowym). Przewaga modelu przyjętego przez zespół prof. Bryanta jest mniej widoczna w codziennym użytkowaniu, ale stanowi gotowe rozwiązanie problemu, z którym, wedle mojej wiedzy, nie borykał się jeszcze żaden z zespołów naukowych zajmujących się edycją naukową; jego wystąpienie jest jednak nieuchronne - to wyłącznie kwestia czasu. Idzie mianowicie o niezgodność praktyk uczonych i programistów w jednej, mającej wszakże zasadnicze znaczenie materii.

W cyfrowej bazie danych ten sam znacznik powinien obsługiwać wszystkie wystąpienia przypisanego mu „bytu”, obojętnie, gdzie ów znacznik jest umieszczony. Oznacza to, że gdy kolejne edycje cyfrowe różnych dzieł i autorów zostaną zamieszczone w tym samym serwisie (czyli będzie je obsługiwać ta sama baza danych), różnym edycjom (być może stworzonym przez innych edytorów) powinien odpowiadać jeden $\mathrm{i}$ ten sam biogram. To $\mathrm{z}$ kolei jest sprzeczne ze znaną nam praktyką, w której nie dość, że biogramy tych samych osób mogą się różnić zależnie od punktu widzenia edytora, to jeszcze stanowią tegoż edytora własność intelektualną. Możliwym rozwiązaniem tego problemu mógłby być powrót do noty indeksowej zamiast przyjętego jako podstawa biogramu, wiąże się to jednak, co oczywiste, $z$ bolesnym okaleczeniem zarówno narracji naukowej, jak i przekazywanej w ten sposób wiedzy. Model zaproponowany przez zespół Bryanta to, jak się rzekło, wygodne i gotowe rozwiązanie, łączy się bowiem z możliwością przejścia przez ten sam ekran pośredni do różnych opracowań biogramu tej samej osoby.

8 Projekt stworzony we współpracy przez mediolańskie Archivio Storico Ricordi i University of Sheffield (Digital Humanities Institute): www.digitalarchivioricordi.com (stan z 12 grudnia 2019 r.).

9 Zob. melville.electroniclibrary.org (stan z 12 grudnia 2019 r.). 
Kolejnym interesującym zagadnieniem są możliwości i zagrożenia związane z wykorzystaniem w opisach znaczników hiperłączy i w ten sposób - uzupełnieniem ich treścią (nie tylko odnośnikiem, jak w edycji papierowej) przypisów / not lub zgoła zastąpieniem jednych drugimi. O szansach, jakie się z tym wiążą, trudno dyskutować; perspektywa zbudowania w jednym miejscu bogatej bazy wiedzy na określony temat jest bowiem oczywistym dobrodziejstwem. Wydaje się, że jeszcze większą, wciąż rozwijaną zdobyczą edycji cyfrowej może być intertekstowe traktowanie narracji w przypisach / notach; chodzi tu o zderzanie ze sobą za pomoca hiperłączy różnych ujęć pod kątem zakresu obserwacji i metod badania tego samego tematu. W związku z tym chciałbym skupić uwagę na mniej wyraźnym, a równie ważnym problemie zagrożeń, z jakimi wiąże się użycie hiperłączy w przypisie cyfrowym, co zresztą w żadnym razie nie neguje płynących z nich korzyści.

Paradoks edycji, nad którą pracowaliśmy, polega na tym, że ślady myślenia o narracji za pomocą hiperłączy będą znacznie bardziej widoczne w tradycyjnej edycji tomu Wierzyński-Lechoń niż w ostatecznej wersji cyfrowej. Wydanie papierowe tych listów często wykorzystuje w przypisach biograficznych odnośniki do specjalistycznych słowników (Polski stownik biograficzny, Wspótcześni polscy pisarze i badacze literatury: stownik biobibliograficzny), zastępujące niejako biogram. Rozwiązanie to zostało zarzucone nie tylko jako nie dość funkcjonalne zarówno w edycji papierowej (wymaga bowiem od czytelnika łącznej lektury książki i słowników), jak i w edycji cyfrowej. W odniesieniu do tej ostatniej przyczyny są dwie. Po pierwsze, część słowników, do których stosowane są odniesienia, wciąż nie ma wersji cyfrowej i nie jest to tylko kwestia digitalizacji - PSB kończy się na literze „S” i w najbliższych latach próżno spodziewać się zakończenia prac nad serią. Tu powraca problem słowników publikowanych przed i989 rokiem, których hasła mogą być obecnie uznawane za niepełne, zwłaszcza w odniesieniu do kultury emigracyjnej, której nasz projekt edytorski jest poświęcony. Drugi powód dotyczy zarazem formy haseł, do których się odnosimy, i odpowiedzialności za ich treść. Odpowiedzialność ta wynika zarówno z kwestii formalnych, jak i technicznych. Nie odpowiadamy za trwałość serwisów innych niż własne; jeśli myślimy o opisach znaczników jako o zbiorach odnośników, może się zdarzyć, że wbrew własnej woli stracimy punkt odniesienia. Słowniki, do których się odwołujemy, mogą stawiać sobie zupełnie inne cele badawcze niż nasz projekt, jednak po włączeniu w edycję za pomocą hiperlinku stają się częścią prowadzonej przez nas narracji naukowej, co może dawać osobliwy efekt. Skrajnym tego przykładem jest norweska edycja dzieł Henrika Ibsena ${ }^{\mathrm{Io}}$, gdzie znaczniki osób dramatu są powiązane z norweskim słownikiem etymologicznym, wyjaśniającym ze ściśle językoznawczej perspektywy sens imion i nazw własnych. W jeszcze więk- 
szym stopniu problem ten może dotyczyć nazw geograficznych. Hasła słownikowe, do których się odnosiliśmy, zazwyczaj zawierają kilka stron tekstu i przedstawiają szczegółowo życiorys danej osoby, na ogół nie wyróżniając punktów zwrotnych w jej życiu ani jej najważniejszych dzieł. Stworzenie skupionych na tych właśnie danych not biograficznych wydaje się wobec tego mieć znaczącą wartość.

Jednakże pewne zmiany nawyków, bardziej charakterystycznych dla indeksowania niż edycji, są podczas pracy nad wydaniem cyfrowym niezbędne, co wynika $\mathrm{w}$ dużej mierze z konieczności rozpisania przytaczanych informacji na bazy danych. Z konieczności oznacza to bardziej (czasem - o wiele bardziej) ścisły podział wiadomości niż to, do czego jesteśmy przyzwyczajeni. Pozornie błahym, ale bardzo wymownym przykładem jest zdarzenie, które przytrafiło się naszemu zespołowi podczas pracy nad listami Wierzyńskiego i Lechonia. W trakcie uzupełniania bazy not biograficznych okazało się, że brakuje biogramu Ireny Wiley, bliskiej przyjaciólki Lechonia. Ze względu na jej miejsce w biografii i korespondencji artysty pozostawienie w bazie takiej luki było niemożliwe. Musieliśmy coś przeoczyć. A jednak okazało się, że w wersji książkowej Irena Wiley nie ma swojego biogramu! Pierwsza wzmianka o niej w bloku korespondencji dotyczy nie jej samej, a jej małżeństwa, w związku z czym małżonkowie John i Irena Wiley otrzymali wspólny przypis, w który są włączone, co oczywiste, biogramy ich obojga. Ta praktyka, dopuszczalna w tradycyjnym wydaniu, w edycji cyfrowej nie jest możliwa z dwóch ważkich powodów. Po pierwsze, każda osoba ma osobne miejsce w bazie danych; szczególnie przy przyjętej przez nas metodzie, w której nota biograficzna towarzyszy wszystkim wzmiankom dotyczącym danej osoby, konieczne jest, aby każdej z nich przypisano własny biogram. Po drugie, jedną z największych zdobyczy, jakie moga przynieść naukowej edycji korespondencji narzędzia cyfrowe, jest możliwość porządkowania listów w inny sposób niż przyjęty w edycji książkowej model linearny, wedle dat nadania. Wydanie cyfrowe - w wyniku decyzji edytorów i dzięki pracy programistów - może umożliwić dowolny wybór spośród kilku porządków lektury; w naszej edycji na przykład podzielenie listów wedle nadawcy czy też czytanie ich w ciągu korespondencji - list i odpowiedź nań - który bardzo często, zwłaszcza przy intensywnej wymianie listów, nie pokrywa się z porządkiem linearnym. Decyzja o opatrzeniu małżonków Wiley wspólnym przypisem jest zatem w wersji cyfrowej „ciałem obcym”, nie tylko niezgodnym $\mathrm{z}$ duchem edycji, ale także uniemożliwiającym stosowanie właściwych jej metod.

Innym zagadnieniem, w obrębie którego pozorna błahostka może prowadzić do poważnych pytań o warsztat pracy edytora cyfrowego, jest oznaczanie innych niż imię i nazwisko sposobów występowania danej osoby w tekście, jak choćby przydomek (czasem czytelny tylko w kręgu korespondentów), pseudonim, epitet 
czy inwektywa. Podczas edycji listów Wierzyński-Lechoń postanowiono oznaczać wszystkie pozwalające na jednoznaczną identyfikację wzmianki o danej osobie, co z punktu widzenia na przykład indeksacji i praktyk redakcyjnych w tym zakresie jest decyzją nieoczywistą. Co ciekawe, wybranie takiego rozwiązania wynikało w pewnej mierze właśnie ze znacznie większej precyzji w indeksacji, którą przynoszą narzędzia cyfrowe. O cóż chodzi? Otóż wykorzystanie systemu TEI pozwala nam zebrać w jednym miejscu wszystkie słowa, które oznaczono tak samo, czyli na przykład przydzielono danej osobie. Dzięki temu czytelnik jednym ruchem palca na klawiaturze może przejść chociażby do wszystkich przydomków i epitetów (a jest ich niemało), jakimi Lechoń i Wierzyński obdarzyli w listach Józefa Czapskiego. Akurat w korespondencji „skamandryckiego trójkąta” inwektyw nie brakuje (zwłaszcza ze strony zapalczywego i nieważącego słów Lechonia), co może skutkować tym, że gdy podczas lektury listów najeżdżamy na oznaczony jako osoba (co implikuje konkretne przyporządkowanie) epitet „grafoman” lub „idiota”, pojawi się wizytówka „Czesław Miłosz”. To jednak prowadzi do bardzo poważnego pytania: jakie są kryteria doboru słów, które oznaczamy?

Już bowiem praktyka oznaczania jako „Czesław Miłosz” wzmianek niezawierających jego personaliów, których przyporządkowanie wymaga wiedzy i interpretacji (abyśmy nie pomylili go z żadnym innym „grafomanem”; grafomanem wedle zawistnego Lechonia), jest gestem nieoczywistym. A jeśli konsekwentnie rozwijać myślenie o przemianie kryteriów edycji wobec konwencji cyfrowej, to zmiany praktyk edytorskich mogą iść jeszcze dalej. W wypadku naszego projektu było to powiązane $\mathrm{z}$ odpowiedzią na kolejne pytanie, tym razem o kryteria doboru - co oznaczamy jako „byty” w standardzie TEI (czyli gdzie przypis zostaje przekształcony w opis znacznika), a co pozostaje w dotychczasowej formie przypisu. Początkowo selekcja zdawała się prosta: wszystko, co należy do wybranych przez nas kategorii „bytów”, staje się opisem znacznika, reszta funkcjonuje w formie przypisu. Domyślnie przyporządkowaniem do kategorii „bytów” był rodzaj omówionej powyżej rozszerzonej indeksacji, czyli rzeczowe, dosłowne lub przenośne, ale jednoznacznie czytelne przywołanie w tekście osoby (miejsca, dzieła, czasopisma, instytucji). O ile jednak w odniesieniu do „bytów” oznaczało to spójne kryterium doboru oznaczeń, o tyle w przypadku przypisów było spójne już mniej; uwidoczniło się dominujące (w rzeczywistości - wyłączne) kryterium selekcji negatywnej (wszystko, co nie pasowało do innych kategorii, zostało przypisem).Zmusiło nas to do krytycznego spojrzenia na kryteria rozstrzygnięcia, co pozostaje przypisem, zaś ta refleksja $z$ kolei - do radykalnej i niespotykanej dotychczas w edycjach cyfrowych decyzji, by w dużym stopniu wziąć pod uwagę nie tylko kryteria wynikające wprost z tekstu, lecz także - z perspektywy odbiorcy. 
Innymi słowy, wiązało się to $\mathrm{z}$ namysłem nad już gotowymi przypisami, czy aby nie są to jednak informacje, których będzie przede wszystkim potrzebował czytelnik zainteresowany konkretną osobą (dziełem, czasopismem). W związku z tym - czy nie powinniśmy, wbrew przyzwyczajeniom wyniesionym $z$ edycji tradycyjnej, uczynić $z$ nich nie przypis, ale notę dotyczącą tej osoby, a następnie poszukać dla nich stosownego punktu zaczepienia w tekście listu? Dobry przykład stanowi tu list Wierzyńskiego do Lechonia z 29 stycznia 1948 roku, w którym pisze on: „data moich zobowiązań wisi mi jak miecz nad głową" ". „Zobowiązaniem” jest tu ukończenie przez Wierzyńskiego biografii Chopina. Doszliśmy do wniosku, że ta wzmianka powinna przede wszystkim trafić do odbiorcy szukającego informacji o Chopinie lub książce o nim i w związku z tym stanowić część powiązanych z tym „bytem” not kontekstowych. Początkowo, zasugerowawszy się charakterem przypisu skupionego wokół daty setnej rocznicy śmierci Chopina, przyporządkowaliśmy notę osobie; ostatecznie jednak uznaliśmy, że przede wszystkim należy ona do zbioru informacji o okolicznościach powstania dzieła - i tam też została przydzielona.

Oczywiście zdajemy sobie sprawę z kontrowersji, jakie mogą budzić tego rodzaju rozwiązania, zwłaszcza wobec znamiennego dla współczesnej sztuki edycji (nie tylko w Polsce) pryncypium jak najdalej idącego odrzucenia decyzji subiektywnych i jednoznacznie interpretacyjnych. $Z$ drugiej strony jesteśmy przekonani, że tak silne wprowadzenie do decyzji edytorskich perspektywy odbioru stanowi nieodzowną konsekwencję możliwości i konwencji wynikających z charakteru środowiska cyfrowego. Wydaje się też, że namysł tego rodzaju logicznie wynika z przełożenia na narzędzia edytorskie założeń polskiej szkoły badań nad recepcją tekstu (Teresa Kostkiewiczowa, Michał Głowiński).

Aby pokrótce przedstawić tylko najważniejsze problemy, jakie napotkaliśmy przy przekształcaniu przypisów w noty towarzyszące znacznikom, trzeba dodać tu koniecznie jeszcze jeden. Znamienne wydaje się, że tak duży fragment niniejszego tekstu został poświęcony przypisom / notom osobowym. Znamienne nie tyle dla liczby i znaczenia tego rodzaju problemów, ile dla rangi, jaką przypisuje się, nawet bezwiednie, w polskiej edycji naukowej przypisom osobowym. Jednym z ciekawszych wniosków podczas pracy nad wydaniem cyfrowym była dysproporcja liczebna między notami osobowymi a wszystkimi pozostałymi, przy czym bezdyskusyjnie największa nieobecność komentarza dotyczy przestrzeni i topografii. O ile w odniesieniu do dzieł czy instytucji można mówić przede wszystkim o notach mniej szczegółowych niż w przypadku osób - notach zdradzających założenie, że raczej tłumaczymy to, co niezbędne, aby pojąć kontekst, niż przedstawiamy zjawisko $a b$ 
ovo, analogicznie do biogramu, o tyle miejsca bardzo często pozostają poza refleksją edytora. $Z$ naszych roboczych obserwacji wynika, że problem ten nie odnosi się tylko do opracowania przypisów w wydaniu listów skamandrytów i dotyka także edytorów, którzy w swojej działalności badawczej zdradzają żywe zainteresowanie kwestiami przestrzennymi. Dobrym przykładem jest tu edycja „prywatnego” dziennika Gustawa Herlinga-Grudzińskiego, dokonana przez prof. Włodzimierza Boleckiego, gdzie liczba przypisów dotyczących przestrzeni jest znacznie niższa niż liczba zawartych w tekście nieoczywistych odniesień topograficznych ${ }^{\mathrm{I} 2}$.Zagadnienie to $\mathrm{z}$ całą pewnością wymaga większej uwagi niż tak krótka wzmianka, istotne jednak wydaje się, że jego rozpoznanie - w obrębie naszego zespołu - zaczęło się nie od autorefleksji, a od konstatacji, jak wiele luk w lokalizacjach przeznaczonych na noty towarzyszy znacznikom przypisanym do konkretnych miejsc.

$\mathrm{Na}$ koniec chciałbym wrócić do jednego z zadanych przeze mnie wcześniej pytań: jakie zmiany sposobu myślenia o komentarzu do tekstu już teraz przynosi znacznik? Co najmniej trzy spośród nich wydają się szczególnie istotne. Pierwszą kwestią jest większa, niż nierzadko dzieje się to w świecie druku, uwaga, z jaką traktujemy fizyczny stan tekstu (jeśli opracowujemy materiał źródłowy). Proces ten zaczyna się zresztą już wcześniej, od innego przygotowania źródła do publikacji: przepisania całej substancji tekstu ze skreśleniami. Podążamy tym samym oczywiście jedną $z$ istniejących ścieżek rozumienia literatury dokumentu osobistego ${ }^{\mathrm{I} 3}$, ale tutaj niejako narzędzia, z których korzystamy, idą w parze $\mathrm{z}$ tego rodzaju sposobem myślenia o tekście, w którym istotny jest jego kształt materialny. Druga zmiana, jaką niesie edytorstwo cyfrowe, to zwrócenie większej uwagi na funkcjonalność przypisu. Podczas opracowania materiału do druku niekoniecznie zastanawiamy się, co w naszym przypisie należy do kontekstu, a co jest informacją definiującą daną osobę czy zjawisko; w praktyce często łączymy oba te elementy. W przypadku edycji cyfrowej częste stawianie takich pytań wydaje się konieczne. W przypisie często reagujemy na coś, co znaleźliśmy w tekście i co trzeba naszym zdaniem wyjaśnić. Znacznik każe nam ponadto zadać sobie pytania: Dlaczego tak to nazywasz? Dlaczego chcesz to osobno wyszukać? Trzecia wreszcie zmiana, sygnalizowana już wcześniej, to znacznie bardziej narracyjny charakter aparatu komentarzy, zwłaszcza biograficznych. W wydaniu tradycyjnym jesteśmy skupieni na sytuacji, która wymaga objaśnienia w danym momencie lektury. W edycji cyfrowej możliwość zgromadzenia wszystkich not $\mathrm{w}$ tym samym miejscu sprawia, że przypisy stają się czymś w rodzaju opowieści tworzącej jedną całość. Dobry przykład w naszej edycji stanowią noty dotyczące

12 Zob. G. Herling-Grudziński, Dziennik 1957-1958, oprac. W. Bolecki, Kraków 2018.

13 Zob. Ph. Lejeune, Wariacje na temat pewnego paktu. O autobiografi, red. R. Lubas-Bartoszyńska, tłum. W. Grajewski et al., Kraków 2001; P.-M. de Biasi, Genetyka tekstóww, tłum. F. Kwiatek, M. Prussak, Warszawa 2015. 
Józefa Czapskiego. Po zebraniu ich razem okazało się, że w dużej mierze oświetlają one $\mathrm{z}$ różnych perspektyw wciąż te same zdarzenia, czytelnik jednak nie dowiaduje się, co je poprzedzało i jaki był ich skutek. W edycji cyfrowej musieliśmy zatem rozbudować przypisy, wypełniając tym samym luki w opowieści.

Pozostaje jeszcze kwestia intertekstualnego dialogu. Wspomniałem powyżej zagrożenia związane $\mathrm{z}$ wykorzystywaniem hiperłączy, jest to jednak oczywista funkcja edycji cyfrowej, która może zmieniać także myślenie o przypisie na poziomie badawczym, nie tylko technicznym czy warsztatowym. Dobrą praktyką edytorską (tu warto znów powołać się na prace Beaty Dorosz, w tym również na jej edycje wcześniejsze niż omawiana ${ }^{\mathrm{I} 4}$ ) jest oświetlanie opracowywanych tekstów odwołaniami do tekstów im najbliższych ${ }^{\text {I5 }}$ lub cytatami z nich. Codzienna praca edytora w środowisku, którego naturalną cechę stanowi intertekstualność, sprawia jednak, że o wiele bardziej zwracamy uwagę na wielość perspektyw wobec tego samego zdarzenia. W przypadku edycji skamandryckiej jest to na przykład rosnące wyczulenie na to, jak na te same sytuacje zapatrywały się inne środowiska emigracyjne z kręgiem „Kultury” na czele.

W ostatecznym rozrachunku odpowiedź na tego rodzaju pytania przestaje już należeć do kwestii narzędzi, jak problem użycia hiperlinków. Przesunięcie pola obserwacji w stronę polifoniczności dyskusji rozumianej jako immanentna cecha edycji staje się obecnie bardziej oczywiste i naturalne. Ów problem przemieszczenia granic dotyczy zresztą całości zagadnienia kształtowania warsztatu edytorskiego w realiach cyfrowych - i pozostaje ufać, że zaprezentowany tekst jest tego widomym świadectwem.

\section{BIBLIOGRAFIA}

\section{ProjeKTY EDYCJI CYFROWEJ PRZYWOEANE W TEKŚCIE:}

Archiwum Ricordi - edycja cyfrowa (kierownik projektu Patrizia Rebulla): www.digitalarchivioricordi.com. Edycja dzieł Henrika Ibsena (kierownik projektu Ellen Rees): www.ibsen.uio.no.

Edycja dzieł Hermana Melville'a (kierownik projektu John Bryant): melville.electroniclibrary.org.

Edycja listów Jana Lechonia i Kazimierza Wierzyńskiego (kierownik projektu Beata Dorosz): tei.nplp.pl. Edycja tekstów i korespondencji Jana Dantyszka (kierownik projektu Anna Skolimowska): dantiscus. al.uw.edu.pl.

SŁOWA KLUCZE: naukowa edycja cyfrowa, przypis, znacznik

14 Zob. M. Grydzewski, J. Lechoń, Listy 1923-1956, oprac. B. Dorosz, Warszawa 2006.

15 W przypadku listów Lechonia będzie to jego dziennik, przy korespondencji Wierzyńskiego - Pamiętnik poety. 


\section{KONRAD NiCIŃSKI}

\section{FOOTNOTES IN DIGITAL EDITING (TEI STANDARD)}

The objective of this paper is to show how the solutions suitable for traditional scholarly editing may work in the digital environment. The central issue of the article is to present the ways of adjusting the annotations (the footnotes in particular) to the rules of scholarly digital editing, and especially to the TEI technical standard. The paper aims to answer the following questions:

- how to make use of the possibilities offered by TEI elements and attributes?

- can the descriptions associated with TEI elements replace traditional foot- or endnotes?

- why do traditional footnotes, once incorporated into digital editing, require further reworking, sometimes both editorial and factual?

KEY wORDs: scholarly digital editing, footnote, TEI elements 